\title{
Productivity, Soil Properties and Economics of Rainfed Pearl Millet as Influenced by Mulching and Organic Sources of Nutrients
}

\author{
Ramawatar Meena, S.K. Maurya and Raj Kumar Meena* \\ Department of Soil Science and Agricultural Chemistry, Institute of Agricultural Sciences, \\ Banaras Hindu University, Varanasi- 221005 (U.P.), India \\ *Corresponding author
}

\section{A B S T R A C T}

\begin{tabular}{|l|}
\hline K e y w o r d s \\
Soil, FYM, \\
Vermicompost, \\
Legume straw \\
mulching, \\
Pearl millet, \\
Soil moisture.
\end{tabular}

Keywords

Soil, FYM,

Vermicompost,

Legume straw

mulching,

Pearl millet,

Soil moisture.

Article Info

Accepted:

Available Online:

10 February 2017

\section{Introduction}

In India, rainfed area constitutes about $68 \%$ of arable land (144 million ha) contributing about $45 \%$ of food grain production. This area is characterized by a higher frequency of uneven distribution of rainfall in time and space often causing dry spells of two weeks or more resulting in moisture stress conditions. If these occur at the critical growth period of crops, the yields are seriously impaired. Thus, the major problem of establishing a crop in the dry season is the lack of adequate moisture in the seed zone in the area.
Mulching checks the loss of soil moisture through evaporation process, suppresses weed growth and provides favourable soil moisture regime for plant growth (Kumar et al., 2006).

Mulches also play an important role in reducing soil erosion, improving soil structure, organic matter, microbial flora, soil aeration, regulating soil temperature, conserving moisture in-situ, controlling weeds and reducing nutrient removal by weeds (Mostert, 1993, Jiang et al., 1997). 
Different organic mulches significantly increased the soil organic carbon and nutrients (Kumar, 2014). The mulching results in higher total and marketable yield as compared to non-mulching treatment (Kumar et al., 2015). Mulches not only conserve soil moisture but also impart manifold beneficial effects, like suppression of extreme fluctuation of soil temperature and reduction of water loss through evaporation, resulting is more stored soil moisture (Shirgure et al., 2003), maintenance of soil fertility (Slathia and Paul, 2012).

Pearl millet (Pennisetum glaucum L.) is one of the major coarse grain crops and is considered to be a poor man's food. In Asia it is an important kharif cereal crop of India, Pakistan, China and south eastern Asia. In India it is one of the important millet crops which flourishes well even under adverse conditions of weather and grown over an area of 8.9 million hectares with total production of 5-7 million tonnes. Nearly half of all food grains are grown under rainfed conditions, and hundreds of millions of poor rural people depend on rainfed agriculture as the primary source of their livelihoods. Maintaining soil moisture level during critical crop growth stages is the key to success of crop production in dry land areas. Pearl millet has relatively high resistance to drought, high production capacity in hot and dry areas and high efficiency of water use of the threecarbon, which is considered the most suitable for the plant growing areas with limited water. This discussion suggests that the adoption of resource conserving technologies, such as zero-tillage and residue management is essential in rainfed condition to improve productivity, resource-use efficiency and sustainability of low input agriculture. Keeping this in view, the present investigation was undertaken to study the combined effect of mulching and organic sources application on soil properties and yield of pearl millet (Pennisetum glaucum L.) crop in rainfed condition.

\section{Materials and Methods}

The experiment was conducted in 2012-2013 at the Agronomy farm of Rajiv Gandhi South Campus, Brakachha (Banaras Hindu University) Mirzapur which is situated in Vindhyan region of district Mirzapur (25 $10^{\circ}$ latitude, $82^{\circ} 37^{\prime}$ longitude and altitude of 427 meters above mean sea level). Vindhyan soil comes under rainfed and invariably poor fertility status. This region comes under agro-climatic zone III A (semi-arid eastern plain zone). The climate of Barkachha is typically semi-arid, characterized by extremes of temperature both in summer and winter with low rainfall and moderate humidity. Maximum temperature in summer is as high as $45^{\circ} \mathrm{C}$ and minimum temperature in winter falls below $10{ }^{\circ} \mathrm{C}$. The annual rainfall of locality was $774.8 \mathrm{~mm}$ in 2013 .

The experiment was laid out in a randomized block design with ten treatments, namely, control without mulch cropping, Legume straw mulch $\left(2.5 \mathrm{t} \mathrm{ha}^{-1}\right)$, Water hyacinth mulch $\left(2.0 \mathrm{t} \mathrm{kg} \mathrm{ha}^{-1}\right)$, Paddy straw mulch $(2.5$ $\left.\mathrm{t} \quad \mathrm{ha}^{-1}\right)$, Legume straw mulch $\left(2.5 \mathrm{t} \mathrm{ha}^{-1}\right)+$ FYM $\left(20 \mathrm{t} \mathrm{ha}^{-1}\right)$, Water hyacinth mulch $(2.0 \mathrm{t}$ $\left.\mathrm{ha}^{-1}\right)+$ FYM $\left(20 \mathrm{t} \mathrm{ha}^{-1}\right)$, Paddy straw mulch $\left(2.5 \mathrm{tha}^{-1}\right)+$ FYM $\left(20 \mathrm{t} \mathrm{ha}^{-1}\right)$, Legume straw mulch $\left(2.5 \mathrm{t} \mathrm{ha}^{-1}\right)+$ FYM $\left(20 \mathrm{t} \mathrm{ha}^{-1}\right)+$ vermicompost $\left(20 \mathrm{t} \mathrm{ha}^{-1}\right)$, Water hyacinth mulch $\left(2.0 \mathrm{t} \mathrm{ha}^{-1}\right)+\mathrm{FYM}\left(20 \mathrm{t} \mathrm{ha}^{-1}\right)+$ vermicompost $\left(20 \mathrm{t} \mathrm{ha}^{-1}\right)$ and paddy straw mulch $\left(2.5 \mathrm{t} \mathrm{ha}^{-1}\right)+$ FYM $\left(20 \mathrm{t} \mathrm{ha}^{-1}\right)+$ vermicompost $\left(20 \mathrm{t} \mathrm{ha}^{-1}\right)$ to pearl millet plot to at the experimental field in 2012- 2013. The treatments were applied to $6.3 \mathrm{~m}^{2}(3.0 \mathrm{~m}$ x $2.10 \mathrm{~m}$ ) plots arranged in a randomized block design with three replications. After ridging the treatment plots, chemical fertilizers were broadcast over the soil in the form of Urea, DAP, MOP, FYM, 
Vermicompost. Pearl millet cv. (ICTP-8203) was sown at a row distance of $45 \mathrm{~cm}$. A plant spacing of $10 \mathrm{~cm}$ within the row was maintained by thinning done about 15 days after sowing. Mulches of Hyacinth straw mulching, Paddy straw mulching and Legume straw mulching were applied at $2 \mathrm{t}$ $\mathrm{ha}^{-1}, 2.5 \mathrm{t} \mathrm{ha}^{-1}$ and $2.5 \mathrm{t} \mathrm{ha}^{-1}$ respectively after next day of sowing in between the rows, allowing plants to grow normally and also ensuring that the rainwater could enter into the soil. The crop was harvested when the ears are nearly dry and entire plants showed physiological maturity. The soil of experimental was sandy loam in texture having $\mathrm{pH} \quad(1: 2.5) \quad 5.9$ and electrical conductivity (EC) $0.55 \mathrm{dS} \mathrm{m}^{-1}$. The soil was low in organic carbon $\left(3.8 \mathrm{~g} \mathrm{~kg}^{-1}\right)$, available $\mathrm{N}\left(136.6 \mathrm{~kg} \mathrm{ha}^{-1}\right)$ and $\mathrm{K}\left(113.3 \mathrm{~kg} \mathrm{ha}^{-1}\right)$, medium in available $\mathrm{P}\left(12.3 \mathrm{~kg} \mathrm{ha}^{-1}\right)$ and. Soil samples from all three replications $(0.15$ $\mathrm{m})$ were taken before starting the experiment and from each treatment after harvest of the crop. The soil samples were air-dried, ground and analyzed for $\mathrm{pH}$ in 1:2.5 soil: water suspension, organic carbon by Walkley and Black (1934); available $\mathrm{N}$ by alkaline potassium permanganate (Subbiah and Asija, 1956); $\mathrm{NaHCO}_{3}$ extractable-P (Olsen et al., 1954) by spectrophotometer, ammonium acetate extractable $\mathrm{K}$ (Hanway and Heidel, 1952) by flame photometer and $0.15 \% \mathrm{CaCl}_{2}$ extractable $\mathrm{S}$ by developing turbidity using $\mathrm{BaSO}_{4}$ (Chesnin and Yien, 1950).

\section{Results and Discussion}

\section{Yield and harvest index (\%)}

Significantly highest pearl millet yield (23.22 $\mathrm{q} \mathrm{ha}{ }^{-1}$ ), straw yield (43.56 $\mathrm{q} \mathrm{ha}^{-1}$ ) and harvest index $(34.78 \%)$ were obtained in the treatment Legume straw mulching + FYM + Vermicompost (Table 1). The lowest yield of pearl millet $\left(16.64 \mathrm{q} \mathrm{ha}^{-1}\right)$ was recorded in control. The relative yield increase in grain and stover under treatment may be attributed to marked increase in yield contributing components like number of effective tillers, ear length, ear diameter, 1000-grain weight, whereas control had lower grain and stover yield attributing characters and finally a decrease in grain and stover yield were obtained (Singh and Singh, 2006). Increase in the yield components might be connected with the release of essential nutrient elements and moisture by the organic matter (Sharma and Vyas, 2001).

\section{Nutrients (NPKS) availability in post harvest soil}

A perusal of data in table 1 indicated a declining trend in available $\mathrm{N}$ status (113.02 $\mathrm{kg} \mathrm{ha}^{-1}$ ) in control after harvest of the crop. However, the maximum nitrogen $(139.90 \mathrm{~kg}$ $\mathrm{ha}^{-1}$ ) was recorded under treatment of Legume straw mulching $+\mathrm{FYM}$ + Vermicompost. These increase in available $\mathrm{N}$ status due to application of Legume straw mulching and FYM with Vermicompost which increase multiplication of soil microbes leading to enhanced conservation of organically bound $\mathrm{N}$ into inorganic forms and rapid mineralization (Walia et al., 2010; Thamaraiselvi et al., 2012). Sharma et al., (2013) who also observed that available $\mathrm{N}$ status in soil increased with application of organic sources along with fertilizers.

The minimum available $\mathrm{P}\left(12.59 \mathrm{~kg} \mathrm{ha}^{-1}\right)$ status was found in control. Incorporation of Legume straw mulching with FYM and Vermicompost recorded significantly higher available $P\left(16.43 \mathrm{~kg} \mathrm{ha}^{-1}\right)$. The increased availability of available $P$ with Vermicompost and FYM could be ascribed to their solubilizing effect on native insoluble $\mathrm{P}$ fraction through release of various acids, thus resulting into a significant improvement in available P status of soil (Urkurkar et al., 2010). In addition, the organic matter may also reduce he fixation of phosphate by providing protective cover on sesqui-oxides 
and thus increase the available $\mathrm{P}$ in soil solution (Bharadwaj et al., 1994).

Application of Legume straw mulching with FYM and Vermicompost increased the available $\mathrm{K}$ content of surface soil over control (Table 2). Higher amount of available $\mathrm{K}\left(286.33 \mathrm{~kg} \mathrm{ha}^{-1}\right)$ was recorded with legume straw mulching + FYM + Vermicompost treatment while minimum K $\left(214.33 \mathrm{~kg} \mathrm{ha}^{-1}\right)$ was found under control. Increase in available $\mathrm{K}$ due to legume straw mulching along with FYM and Vermicompost may be attributed to the direct addition of $\mathrm{K}$ to the available pool of the soil. This may probably also be due to solubilized $\mathrm{K}$ from K-bearing minerals by the organic acids released as a decomposition of organic materials. The increase in integrated treatments might be due to addition of organic matter that reduce $\mathrm{K}$-fixation and release $\mathrm{K}$ due to interaction of organic matter with clay (Subehia and Sepehya, 2012; Urkurkar et al., 2010). The content of sulphate $\mathrm{S}$ as influenced under different treatments was found to vary from 13.73 to $21.40 \mathrm{~kg} \mathrm{ha}^{-1}$ which was minimum in the control and maximum $\left(21.40 \mathrm{~kg} \mathrm{ha}^{-1}\right)$ under treatment Legume straw mulching + FYM + Vermicompost. Incorporation of different type of mulching along with FYM and Vermicompost increased the sulphate-S content. Similar results were found by Reddy et al., (2004).

\section{Soil moisture at different soil depth}

The data on soil moisture at different stages of observations under mulches with different organic sources is presented in table 2. The moisture conservation affected pearl millet crop significantly during the crop season. But treatments were found non significant at the 20 DAS. Soil moisture conserve at different level of depth of experimental field under pearl millet crop increased with the advancement of the crop age. During the period of various type of mulching with organic sources in the 2012-13 the general soil moisture content depended on meteorological conditions. The maximum soil moisture at 20,40,60 days and at harvest under 0-15, 15-30, 30-45 and 45-60 cm depth were recorded $15.97,15.20,15.82$, and 15.55 $\%$ respectively with the treatment of Legume straw mulching + FYM + Vermicompost compare to other treatment. Similar to this report was provided by Igwa et al., (2005)

\section{Physico-chemical properties of soil}

The range and mean values of analyzed relevant soil physicochemical properties are presented in table 2. All the soils were acidic in reaction with mean $\mathrm{pH}$ varied from 4.70 to 5.60. The EC mean values ranged from 0.38 to $0.53 \mathrm{dS} \mathrm{m}^{-1}$. The OC content of these soils were varied from $32 \%$ to $0.50 \%$. The data indicated that there was non-significant effect was observed on physical properties of soil except water holding capacity of experimental field. The maximum water holding capacity $52.50 \%$ was recorded under treatment Legume straw mulching + FYM + Vermicompost and minimum water holding capacity is $38.98 \%$ under control. This might be due more organic matter in the soil compare to control and other treatment.

The percent increasing maximum water holding capacity is $38.23 \%$ than the control. Similarly results are observed by Biswas and Khosla (1971), Bhatia and Shukla (1982). Application of vermicompost at 5 tonnes per ha increased maximum water holding capacity compared to control as reported by Jadhav et al., (1993). 
Table.1 Effect of mulching and organic sources of nutrients on yield and available NPKS in post harvest soil under pearl millet crop in rainfed condition

\begin{tabular}{|c|c|c|c|c|c|c|c|}
\hline Treatment & $\begin{array}{c}\text { Grain } \\
\text { yield } \\
\left(\mathbf{q} \mathbf{h a}^{-1}\right)\end{array}$ & $\begin{array}{c}\text { Stover } \\
\text { yield } \\
\left(\mathbf{q} \mathbf{h a}^{-1}\right)\end{array}$ & $\begin{array}{c}\text { Harvest } \\
\text { index } \\
(\%)\end{array}$ & $\begin{array}{l}\text { Available N } \\
\left(\mathrm{Kg} \mathrm{ha}^{-1}\right)\end{array}$ & $\begin{array}{l}\text { Available P } \\
\left(\mathrm{Kg} \mathrm{ha}^{-1}\right)\end{array}$ & $\begin{array}{l}\text { Available K } \\
\left(\mathrm{Kg} \mathrm{ha}^{-1}\right)\end{array}$ & $\begin{array}{l}\text { Available } S \\
\left(\mathrm{Kg} \mathrm{ha}^{-1}\right)\end{array}$ \\
\hline $\mathbf{T}_{1}$-Control & 16.64 & 34.80 & 32.33 & 113.02 & 12.59 & 214.33 & 13.73 \\
\hline $\mathbf{T}_{2}-\operatorname{LSM}\left(2.5 \mathrm{t} \mathrm{ha}^{-1}\right)$ & 19.31 & 36.73 & 34.53 & 126.63 & 13.49 & 263.33 & 16.97 \\
\hline $\mathrm{T}_{3}$-WHM (2.0 t kg ha $\left.{ }^{-1}\right)$ & 18.32 & 35.20 & 34.27 & 120.54 & 13.70 & 259.00 & 17.63 \\
\hline $\mathrm{T}_{4}-\operatorname{PSM}\left(2.5 \mathrm{t} \mathbf{h a}^{-1}\right)$ & 17.38 & 35.10 & 33.16 & 122.68 & 12.87 & 257.67 & 18.33 \\
\hline $\begin{array}{c}\text { T}_{5}-\operatorname{LHM}\left(2.5 \mathrm{t} \mathrm{ha}^{-1}\right)+\text { FYM } \\
\left(20 \mathrm{t} \mathrm{ha}^{-1}\right)\end{array}$ & 20.21 & 38.74 & 34.28 & 132.93 & 15.21 & 268.00 & 16.40 \\
\hline $\begin{array}{l}\text { T6-WHM }_{6}\left(2.0 \mathrm{t} \mathrm{ha}^{-1}\right)+\text { FYM } \\
\left(20 \mathrm{t} \mathrm{ha}^{-1}\right)\end{array}$ & 20.15 & 38.70 & 34.26 & 128.53 & 15.74 & 211.33 & 13.80 \\
\hline $\begin{array}{l}\text { T }_{7}-\text { PSM }\left(2.5 \mathrm{tha}^{-1}\right)+\text { FYM }(20 \\
\left.\text { t ha }^{-1}\right)\end{array}$ & 19.61 & 37.33 & 34.50 & 130.93 & 14.08 & 256.33 & 19.93 \\
\hline $\begin{array}{c}\text { T}_{8}-\mathrm{LSM}\left(2.5 \mathrm{t} \mathrm{ha}^{-1}\right)+\text { FYM }(20 \\
\left.\mathrm{t} \mathrm{ha}^{-1}\right)+\mathrm{VC}\left(20 \mathrm{t} \mathrm{ha}^{-1}\right)\end{array}$ & 23.20 & 43.56 & 34.78 & 139.90 & 16.43 & 286.33 & 21.40 \\
\hline $\begin{array}{c}\text { T9-WHM }_{9}\left(2.0 \mathrm{t} \mathrm{ha}^{-1}\right)+\text { FYM }(20 \\
\left.\text { t ha-1 }^{-1}\right)+ \text { VC }\left(20 \mathrm{t} \mathrm{ha}^{-1}\right)\end{array}$ & 22.69 & 42.52 & 34.42 & 133.03 & 16.19 & 280.00 & 20.77 \\
\hline 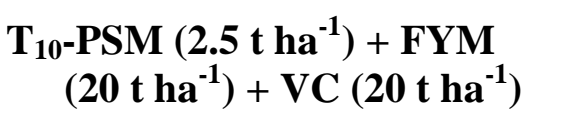 & 21.44 & 40.72 & 34.49 & 135.56 & 15.25 & 270.67 & 18.90 \\
\hline SEm \pm & 1.62 & 0.73 & 0.97 & 0.28 & 1.27 & 0.51 & 3.62 \\
\hline $\mathrm{CD}(\mathrm{P}=\mathbf{0 . 0 5})$ & 4.83 & 2.16 & 2.87 & 0.82 & 3.77 & 1.52 & 10.75 \\
\hline
\end{tabular}


Table.2 Effect of mulching and organic sources of nutrients on moisture content and physicochemical properties of soil under pearl millet crop in rainfed condition

\begin{tabular}{|c|c|c|c|c|c|c|c|c|c|c|}
\hline \multirow[b]{2}{*}{ Treatments } & \multicolumn{4}{|c|}{$\begin{array}{l}\text { Soil moisture content }(\%) \text { at } 0 \text { - } \\
60 \mathrm{~cm} \text { depth at harvest }\end{array}$} & \multicolumn{6}{|c|}{ Physicochemical properties of post harvest soil } \\
\hline & $\begin{array}{l}0-15 \\
\text { cm }\end{array}$ & $\begin{array}{c}15-30 \\
\text { cm }\end{array}$ & $\begin{array}{c}30-45 \\
\text { cm }\end{array}$ & $\begin{array}{l}45-60 \\
\mathrm{~cm}\end{array}$ & pH & $\begin{array}{c}\text { EC } \\
(\mathbf{d S m}-1)\end{array}$ & $\begin{array}{c}\text { Organic } \\
\text { Carbon } \\
(\%)\end{array}$ & $\begin{array}{c}\text { Bulk } \\
\text { Density } \\
\text { (g/cc) }\end{array}$ & $\begin{array}{c}\text { Particle } \\
\text { Density } \\
\text { (g/cc) }\end{array}$ & $\begin{array}{l}\text { WHC } \\
(\%)\end{array}$ \\
\hline $\mathbf{T}_{1}$-Control & 12.71 & 7.35 & 12.18 & 11.30 & 5.13 & 0.50 & 0.32 & 1.41 & 2.30 & 37.98 \\
\hline $\mathrm{T}_{2}-\operatorname{LSM}\left(2.5 \mathrm{t} \mathrm{ha}^{-1}\right)$ & 14.16 & 12.96 & 13.75 & 12.61 & 4.93 & 0.48 & 0.35 & 1.37 & 2.43 & 40.82 \\
\hline $\mathrm{T}_{3}$-WHM $\left(2.0 \mathrm{t} \mathrm{kg} \mathrm{ha}^{-1}\right)$ & 12.85 & 12.29 & 11.88 & 12.33 & 5.43 & 0.41 & 0.35 & 1.39 & 2.36 & 39.03 \\
\hline $\mathrm{T}_{4}-\operatorname{PSM}\left(2.5 \mathrm{t} \mathrm{ha}^{-1}\right)$ & 13.48 & 13.10 & 13.16 & 12.93 & 5.00 & 0.43 & 0.36 & 1.40 & 2.37 & 38.77 \\
\hline $\begin{array}{l}\mathrm{T}_{5}-\mathrm{LHM}\left(2.5 \mathrm{tha}^{-1}\right)+\text { FYM }(20 \mathrm{t} \\
\left.\mathrm{ha}^{-1}\right)\end{array}$ & 13.87 & 13.59 & 15.03 & 14.15 & 5.60 & 0.42 & 0.43 & 1.36 & 2.27 & 43.60 \\
\hline $\begin{array}{l}T_{6}-W H M\left(2.0 \mathrm{t} \mathrm{ha}^{-1}\right)+\text { FYM }(20 \mathrm{t} \\
\left.\mathrm{ha}^{-1}\right)\end{array}$ & 13.47 & 14.48 & 13.91 & 14.73 & 4.97 & 0.38 & 0.39 & 1.38 & 2.56 & 41.43 \\
\hline 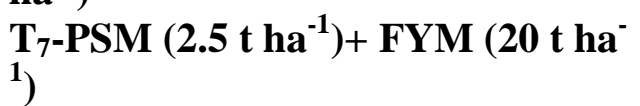 & 14.75 & 15.20 & 13.66 & 14.36 & 4.70 & 0.48 & 0.41 & 1.37 & 2.38 & 42.07 \\
\hline $\begin{array}{l}\text { T}_{8}-\mathrm{LSM}\left(2.5 \mathrm{tha}^{-1}\right)+\text { FYM }(20 \mathrm{t} \\
\left.\mathrm{ha}^{-1}\right)+\mathrm{VC}\left(20 \mathrm{tha}^{-1}\right)\end{array}$ & 15.97 & 14.12 & 15.82 & 15.55 & 4.87 & 0.53 & 0.50 & 1.30 & 2.39 & 52.50 \\
\hline $\begin{array}{c}\text { T9-WHM }_{9}\left(2.0 \mathrm{t} \mathrm{ha}^{-1}\right)+\text { FYM }(20 \mathrm{t} \\
\left.\mathrm{ha}^{-1}\right)+ \text { VC }\left(20 \mathrm{t} \mathrm{ha}^{-1}\right)\end{array}$ & 14.61 & 13.80 & 14.64 & 14.77 & 4.77 & 0.50 & 0.42 & 1.35 & 2.40 & 49.23 \\
\hline $\begin{array}{c}T_{10}-\text { PSM }\left(2.5 \mathrm{tha}^{-1}\right)+\text { FYM }(20 \mathrm{t} \\
\left.\mathrm{ha}^{-1}\right)+ \text { VC }\left(20 \mathrm{tha}^{-1}\right)\end{array}$ & 15.09 & 13.96 & 15.69 & 14.61 & 4.83 & 0.48 & 0.46 & 1.33 & 2.20 & 50.97 \\
\hline SEm \pm & 1.03 & 0.80 & 1.17 & 1.93 & 3.37 & 21.91 & 38.83 & 4.95 & 12.7 & 0.52 \\
\hline $\mathrm{CD}(\mathrm{P}=0.05)$ & 3.06 & 2.37 & 3.48 & 5.74 & NS & NS & NS & NS & NS & 1.56 \\
\hline
\end{tabular}

LSM- Legume straw, WHM- Water hyacinth, PSM- Paddy straw mulch, FYM- Farm yard manure, VC- Vermicompost 
Table.3 Effect of mulching and organic sources of nutrients on economics under pearl millet crop in rainfed condition

\begin{tabular}{|c|c|c|c|c|c|c|}
\hline Treatment & $\begin{array}{c}\text { Cost of } \\
\text { cultivation } \\
\left(\text { Rs. ha } \text { ha }^{-1}\right)\end{array}$ & $\underset{(\text { Rs. hain }}{\text { Grain }}$ & $\begin{array}{c}\text { Straw } \\
\left(\text { Rs. } \text { ha }^{-1}\right)\end{array}$ & $\begin{array}{l}\text { Gross return } \\
\left(\text { Rs. ha } \mathbf{h}^{-1}\right)\end{array}$ & $\begin{array}{l}\text { Net return } \\
\left(\text { Rs. ha }^{-1}\right)\end{array}$ & $\begin{array}{c}\text { Benefit: } \\
\text { Cost } \\
\text { ratio }\end{array}$ \\
\hline $\mathbf{T}_{1}$-Control & 14205.00 & 19552.00 & 15660.00 & 35212.00 & 21007.00 & 1.48 \\
\hline $\mathbf{T}_{2}-\operatorname{LSM}\left(2.5 \mathrm{t} \mathrm{ha}^{-1}\right)$ & 16161.00 & 22689.25 & 16528.50 & 39217.75 & 23056.75 & 1.43 \\
\hline $\mathrm{T}_{3}$-WHM (2.0 t kg ha $\left.{ }^{-1}\right)$ & 18198.00 & 21526.00 & 15840.00 & 37366.00 & 19168.00 & 1.05 \\
\hline $\mathrm{T}_{4}-\operatorname{PSM}\left(2.5 \mathrm{t} \mathbf{h a}^{-1}\right)$ & 17165.00 & 20421.50 & 15795.00 & 36216.50 & 19051.50 & 1.11 \\
\hline $\begin{array}{c}\text { T }_{5}-\mathrm{LHM}\left(2.5 \mathrm{tha}^{-1}\right)+\text { FYM }(20 \mathrm{t} \\
\left.\mathrm{ha}^{-1}\right)\end{array}$ & 18161.00 & 23746.75 & 17433.00 & 41179.75 & 23018.75 & 1.27 \\
\hline $\begin{array}{l}\text { T }_{6}-\text { WHM }\left(2.0 \mathrm{t} \mathrm{ha}^{-1}\right)+\text { FYM }(20 \mathrm{t} \\
\left.\mathrm{ha}^{-1}\right)\end{array}$ & 20198.00 & 23676.25 & 17415.00 & 41091.25 & 20893.25 & 1.03 \\
\hline $\begin{array}{l}\mathrm{T}_{7-P S M}\left(2.5 \mathrm{tha}^{-1}\right)+\text { FYM }(20 \mathrm{t} \\
\left.\text { ha }^{-1}\right)\end{array}$ & 19165.00 & 23041.75 & 16798.50 & 39840.25 & 20675.25 & 1.08 \\
\hline $\begin{array}{c}\text { T}_{8}-\operatorname{LSM}\left(2.5 \mathrm{tha}^{-1}\right)+\text { FYM }(20 \mathrm{t} \\
\left.\mathbf{h a}^{-1}\right)+\operatorname{VC}\left(20 \mathrm{tha}^{-1}\right)\end{array}$ & 21161.00 & 27260.00 & 19602.00 & 46862.00 & 25701.00 & 1.51 \\
\hline $\begin{array}{c}\text { T9-WHM }_{9}\left(2.0 \mathrm{t} \mathrm{ha}^{-1}\right)+\text { FYM }(20 \mathrm{t} \\
\left.\mathrm{ha}^{-1}\right)+ \text { VC }\left(20 \mathrm{t} \mathrm{ha}^{-1}\right)\end{array}$ & 23198.00 & 26660.75 & 19134.00 & 45794.75 & 22596.75 & 0.97 \\
\hline $\begin{array}{c}\text { T }_{10}-\text { PSM } \\
\left.h^{-1}\right)+ \text { VC }\left(20 \mathrm{ha}^{-1}\right)+\text { FYM }(20 \mathrm{t} \\
\left.\mathrm{ha}^{-1}\right)\end{array}$ & 22165.00 & 25192.00 & 18324.00 & 43516.00 & 21351.00 & 0.96 \\
\hline
\end{tabular}


Economics of pearl millet with varying mulching and organic sources of nutrients

The cost of cultivation under different treatment ranged from Rs. 14205 to Rs. 23198 (Table 3). The maximum cost of cultivation (Rs. 23198) was observed in Water hyacinth mulch + FYM +Vermicompost. Minimum cost of cultivation (Rs. 14205) was observed in Control. In pearl millet grain the maximum return (Rs. 27260) was observed in Legume straw mulching + FYM + Vermicompost. The maximum (Rs. 25701.00) net returns was obtained in Legume straw mulching + FYM + Vermicompost, whereas minimum (Rs. 21007.00) was in control. The benefit cost ratio under mulching and organic sources from 0.96 to 1.51 . The benefit cost ratio was obtained maximum 1.51 in Legume straw mulching + FYM + Vermicompost which was superior to other. Similar finding reported by Kavimani et al., (2000) reported the highest benefit cost ratio of 2.23 of pearl millet was obtained with the application of 40 $\mathrm{kg} \mathrm{N} \mathrm{ha}{ }^{-1}$, followed by the combined application of $5.0 \mathrm{tha}^{-1} \mathrm{FYM}$ and $40 \mathrm{~kg} \mathrm{~N}$.

\section{Acknowledgement}

The authors are thankful to the Head, Department of Soil Science \& Agricultural Chemistry, Institute of Agricultural Sciences, Banaras Hindu University, Varanasi, Uttar Pradesh for providing necessary facilities to conduct this research work.

\section{References}

Bharadwaj, V. and Omanwar, P.K. 1994. Longterm effects of continuous rotational cropping and fertilization on crop yields and soil properties. II. Effects on EC, $\mathrm{pH}$, organic matter and available nutrients of soil. J. Indian Soc. Soil Sci., 42: 387-392.

Bhatia, K.S. and Shukla, K.K. 1982. Effect of continuous application of fertilizers and manure on some physical properties of eroded alluvial soil. J. Indian Soc. Soil Sci., 30: 33-36.

Biswas, T.D. and Khosla, B.K. 1971.Building up of organic matter status the soil and its relation to the soil physical properties. Proceedings of International Symposium on Soil Fertility Evaluation, New Delhi, pp. 831-842.

Chesin, L. and Yein, C.H. 1950.Turbidimetric determination of available sulphur. Soil Sci. Soc. America Proc., 15: 149-151.

Hanway, J.J. and Heidel, H. 1952. Soil analyses method as used in Iowa State College Soil Testing Laboratory. Iowa Agric., 57: 1-31.

Igwa, C.A. 2005. Soil physical properties different management systemsand organic matter effects on soil moisture along soil catona insoutheastern Nigeria. Trop. Subtrop. Agroecosyst., 5: 57-66.

Jadhav, S.B., Jadhav, M.B., Joshi, V.A. and Jagatap, P.B. 1993. Organic farming in the light of reduction in use of chemical fertilizers. Proceedings of $43^{\text {rd }}$ Annual Deccan Sugar Technology Association, Pune Part I, pp. SA53-SA65.

Jiang, P., Zhao, X.X., Zhang, R.R. and Wang, Y.S. 1997. Effect of mulching in the hillside citrus orchard. South China Fruits, 26(3): 17- 18.

Kavimani, R., Annadurai, K. Vijayabaskaran, S. and Rangaraju, G. 2001. Effect of farm yard manure and nitrogen on growth and yield of pearlmillet under rainfedalfisol. Madras Agricultural J., 87(10/12): 713714.

Kumar, N., Chandra, S. and Srivastava, A.K. 2006. Mulching: An effective tool for sustainable agriculture in rainfed farming. Indian Farmers Digest, 39(6): 30-33.

Kumar, R., Singh, A., Hooda, V., Singh, R.K. and Singh, M. 2015. Effect of organic manures, bio-fertilizer and mulching on growth and yield of Potato (SolanumTuberosum L.).The Bioscan, 10(1): 403- 406.

Kumar, V. 2014. Effect of different organic mulching materials on soil properties of NA '7' Aonla (Emblica officinalis gaertn) under rainfed condition of shiwalik foothills of Himalayas, India. The Bioscan, 9(1): 561-564. 
Mostert, P.G. 1993. Mulching in citrus. Inligtings bulleting- Institute virTropiese en Subtropiese Gewasse.p. 731.

Reddy, K.S., Singh, M., Tripathi, A.K., Swarup, A. and Dwivedi, A.K. 2004.Changes in the organic and inorganic fractions $\mathrm{S}$ mineralization in a Typic Haplustert after long-term cropping with different fertilizers and organic manure inputs. Australian J. Soil Res., 39: 737-48.

Sharma, G.D., Risikesh, Thakur, Som Raj, Kauraw, D.L. and Kulhare, P.S. 2013. Impact of integrated nutrient management on yield, nutrient uptake, protein content of wheat (Triticum astivam) and soil fertility in a typichaplustert. The Bioscan, 8(4): $1159-1164$.

Sharma, S.C. and Vyas, A.K. 2001.Residual effect of phosphorous fertilization and farmyard manure on productivity of succeeding wheat (Triticumaestivum) after soyabean (Glycine max). Indian J. Agron., 46(3): 416-420.

Shirgure, P.S., Sonkar, R.K., Singh, S. and Panigrahi, P. 2003. Effect of different mulches on soil moisture conservation, weed reduction, growth and yield of drip irrigated Nagpur mandarin. Indian J. Agri. Sci., 73(3): 148-152.

Singh, A. and Singh, N.P. 2006. Direct and residual effects of organic and inorganic sources of nutrients under urdbean (Vigna mungo) wheat (Triticum aestivum) cropping sequence in foot hills of Uttaranchal. Indian J. Agron., 51(2): 9799.

Slathia, P.S. and Paul, N. 2012. Traditional practices for sustainable livelihood in Kandi belt of Jammu. Indian J. Traditional Knowledge, 11(3): 548-552.

Subbiah, B. and Asija, G.L. 1956. Alkaline permanganate method of available nitrogen determination. Curr. Sci., 25: 259.

Subehia, S.K. and Sepehya, S. 2012. Influence of Long-Term Nitrogen Substitution through Organics on Yield, Uptake and Available Nutrients in a Rice-Wheat System in an Acidic Soil. J. Indian Soci. Soil Sci., 60(3): 213-217.

Thamaraiselvi, T., Brindha, S., Kaviyarasi, N.S., Annadurai, B. and Gangwar S.K. 2012: Effect of organic amendments on the bio chemical transformations under different soil conditions. Int. J. Adv. Biol. Res., 2: 171-173.

Urkurkar, J.S., Tiwari, A., Chitale, S. and Bajpai, R.K. 2010. Influence of long term use of inorganic and organic manures on soil fertility and sustainable productivity of rice (Oryzasativa) and wheat (Triticum aestivum) in Inceptisols. Indian. J. Agric. Sci., 80(3): 208- 212.

Walia, M.K., Walia, S.S., and Dhaliwal. 2010. Long term effect of integrated nutrient management of properties of TypicUstochrept after 23 cycles of an irrigated rice (Oryza sativa L.)-wheat (Triticum aestivum L.) system. $J$. Sustainable Agri., 34(7): 724-743.

Walkley, A. and Black, C.A. 1934. Estimation of organic carbon by chromic acid and titration method. Soil Sci., 37: 28-29.

\section{How to cite this article:}

Ramawatar Meena, S.K. Maurya and Raj Kumar Meena. 2017. Productivity, Soil Properties and Economics of Rainfed Pearl Millet as Influenced by Mulching and Organic Sources of Nutrients. Int.J.Curr.Microbiol.App.Sci. 6(2): 566-574. doi: http://dx.doi.org/10.20546/ijcmas.2017.602.064 